\title{
Geographical vs institutional factors of the development of old industrial regions in industry 4.0: the case of Ural macro-region
}

\author{
I.I. Rakhmeeva \\ Ural State University of Economics, Ekaterinburg, Russia; smartreg66@gmail.com
}

\begin{abstract}
Relevance. Massive industrial and economic changes, which are a part of the Fourth Industrial Revolution, bring about new challenges and opportunities for regional development. The factors that used to play a key role in the development of regions such as labor, capital and geography, are now receding to the background while other factors such as technological progress, human capital and institutions gain importance. Research objective. The article deals with changes in the factors that shape regional development, more specifically, it aims to compare the influence of geographical and institutional factors on the development of one of the leading industrial macro-regions in Russia - the Urals. Data and methods. The research contains regional analysis of geographical and institutional factors in old industrial regions of the Ural macroregion of Russia. The method of geographical zoning is based on collation the development levels of regions with their geographical and institutional competitive positions. Results. The research revealed the complexity of factors affecting old industrial regions in Russia in the 2010s: some of these regions are still highly dependent on geographical factors while others are largely shaped by institutional factors. Such territories show sustainable development of their economies and innovation sectors. We also found a significant correlation between the regions' economic performance and their formal institutions (the quality of regulation) while the differences in informal institutions were negligible. Conclusions. The conclusion is made that regional authorities in Russia should put more effort into creating a better regulatory environment for innovation and industry.
\end{abstract}

\section{KEYWORDS}

geographical factors, institutional factors, development factors, old industrial region, fourth industrial revolution, regulatory environment

\section{FOR CITATION}

Rakhmeeva, I.I. (2020)

Geographical vs institutional factors of the development of old industrial regions in industry 4.0: the case of Ural macro-region. R-economy, 6(4), 280-291. doi: 10.15826/recon.2020.6.4.025

\section{Географические vs институциональные факторы развития старопромышленных регионов в индустрии 4.0: пример Уральского макрорегиона России}

\section{И.И. Рахмеева}

Уральский государственньй экономический университет, Екатеринбург, Pоссия; smartreg66@gmail.com

\begin{abstract}
АННОТАЦИЯ
Актуальность. Массовые промышленные и экономические изменения, которые являются частью четвертой промышленной революции, создают новые проблемы и возможности для регионального развития. Факторы, которые раньше играли ключевую роль в развитии регионов, такие как труд, капитал и география, теперь отходят на второй план, в то время как другие факторы, такие как технический прогресс, человеческий капитал и институты, приобретают значение. Цель исследования. В статье рассматривается изменение факторов, определяющих региональное развитие, в частности, проводится сравнение влияния географических и институциональных факторов на развитие одного из ведущих промышленных макрорегионов России - Урала. Данные и методы. Исследование содержит региональный анализ географических и институциональных факторов в старопромышленных регионах Уральского макрорегиона России. Метод географического зонирования основан на сопоставлении уровней развития регионов с их географическими и институциональными конкурентными позициями. Результаты. Исследование выявило комплексное влияние факторов на развитие старопромышленных регионов в 2010-е годы: некоторые из этих регионов все еще сильно зависят
\end{abstract}

\section{КЛЮЧЕВЫЕ СЛОВА}

географические факторы, институциональные факторы, факторы развития, старопромышленный регион, четвертая промышленная революция, регуляторная среда 
от географических факторов, тогда как другие в значительной степени определяются институциональными факторами. Такие территории демонстрируют устойчивое развитие своей экономики и инновационного сектора. Также была обнаружена существенная корреляция уровня развития с качеством формальных институтов (качеством регулирования), в то время как различия в неформальных институтах были незначительными. Выводы. Делается вывод о том, что региональные власти в России должны приложить больше усилий для создания лучшей нормативной среды для инноваций и промышленности.

\section{ДЛЯ ЦИТИРОВАНИЯ}

Rakhmeeva, I.I. (2020)

Geographical vs institutional factors of the development of old industrial regions in industry 4.0 : the case of Ural macro-region.

R-economy, 6(4), 280-291. doi: 10.15826/recon.2020.6.4.025

\section{Introduction}

Geographical factors played a fundamental role in shaping economic systems. At the same time, the significance of space is transformed in Industry 4.0. Economists have justified the role of other factors (e.g. institutions) in economic development. The causes of regional inequality have also attracted much scholarly attention. We believe that humanity is on the threshold of the third institutional revolution today (Animitsa, Rakhmeeva, 2020, p. 211), which will fundamentally change the nature of economic actors' interactions.

The purpose of this paper is to compare the influence of geographical and institutional factors in the era of the fourth industrial revolution for Russian regions. This purpose determines the following research objectives:

- to clarify the role of geographical and institutional factors for development in Industry 4.0;

- to propose a method for assessing geographical and institutional development factors and their impact on the level of development of old industrial regions;

- to test the proposed methodology by using the case of the Ural macro-region and identify the role different factors play in its development in the 2010s.

\section{Theoretical foundation}

P. Krugman, M. Fujita, T. Venables, F. Martin, and others created a new research genre called 'new economic geography' in the 1990s, which focused on the role of institutions in regional development.

Development factors vary in terms of their intensity and significance over time. In this paper, we are going to compare the impact of geographical and institutional factors on the development of old industrial regions in Russia at the current stage by using the method of geographical zoning.

Economists (Kirdina, 2016, p. 139; Lorenz, Hemmer, \& Ahlfeld, 2005; Parent, \& Zouache, 2012; and others) debate about the primacy of development factors. Views on this issue among regionalists are usually divided into geographical determinism, indeterminism and possibilism.

Some scholars put the main emphasis on the significance of geographical factors. For example, Sachs (2003) measured the direct impact of geography on per capita income and concluded that it was superior to institutions. The geographical factors still prevail for certain areas of development, for example, the development of cross-regional innovation systems. F. Cappellano and A. Rizzo (2019) investigated several such systems and concluded that geographical factors dominated for them, while the institutional factors were the least important among the analyzed ones. A study conducted by Russian economists in 65 countries confirmed that climate determines the unique character of historically dominant institutions (Kirdina, 2016, p. 144). Geographical determinist R. Pipes (1974) justified the crucial role of natural factors in the development of Russia.

Other scholars (Connor \& Dovers, 2004; Rodrik, Subramanian, \& Trebbi, 2002; Vogelpohl \& Aggestam, 2012, p. 57) pointed out the primacy of institutional factors for the development of regional systems. The agenda of regional institutional analysis includes the composition of regional institutional development environments for different regions, identification and analysis of formal and informal institutions. The solution of these problems can become a significant contribution to the sustainable development of regions (Tambovtsev, 2019, p. 104).

The above-described contradiction stems from the uniqueness of various socio-economic systems and the changes in the degree of influence that different factors have on these systems. This trend is not unique to Russia but encompasses the whole world: while the availability of mineral resources and geographical location were important in the early industrial era, human capital and institutions are what matters the most in the post-industrial era (North, 1990; Acemoglu \& Robinson, 2012) and the fourth industrial revolution is going to change the situation even more. 
The acceleration of scientific and technological progress is a generally recognized fact. Thus, we can speak of the shift in the significance of development factors, the constant evolution of the socio-economic systems and the formation of a new economic paradigm. The research on this topic should continue because the world economic order is changing (Glazyev et al., 2018) and the global socio-economic system has not yet moved from the bifurcation zone towards a new attractor, in which the system is likely to reach a temporarily stable state (at least for the lifetime of one generation).

In this article we are going to assess the influence of geographical and institutional factors on the development of territories of the Ural macro-region by applying the method of geographical zoning and comparative analysis.

The research of the influence of geography and institutions is a methodologically complex task due to the multiplicity of factors and the complexity of measurement (Kirdina, 2016, p. 139, Frolov, 2015, p. 15).

\section{Geographical factors}

Progress reduces the value of distance but increases the value of a specific territory. K. Marx was the first to describe this phenomenon in 'Capital' (1894, Ch. 39).

The development of new technologies allows to expand the geography of production by digital description, avoiding trade barriers (Mokronosov, Anisimov, 2019, p. 253). Special organizations help accelerate the diffusion of knowledge and technology (Morisson, 2019, p. 98).

Z. Chen et al. (2019) discuss the influence of the high speed rail as the main factor in the development of the new economic geography in China.

In Russia, the factor of physical space has played a significant role since ancient times with its vast distances (Fig. 1). The same can be said about the harsh climate in most of the country's territory. This determined the deep interest of researchers in this issue and their attempts to explain institutions and economics through geographical and natural factors (Mironov, 2014, p. 131). Geography determines state policy in modern Russia (Gorshkov, 2015, pp. 284-285).

The need to lower the barriers of spatial development is obvious, but they are persistent and the problem seems too big to solve. 'Space is very inertial: the settlement system is slowly changing, and infrastructure development has very high costs. The choice of priority areas for lowering development barriers is limited for Russia by an even narrower 'corridor of opportunities' due to depopulation, the huge size of the territory and crisis problems. Sooner or later, we will have to make a choice in favor of the most flexible factor - modernization of institutions' (Zubarevich, 2010, p. 4).

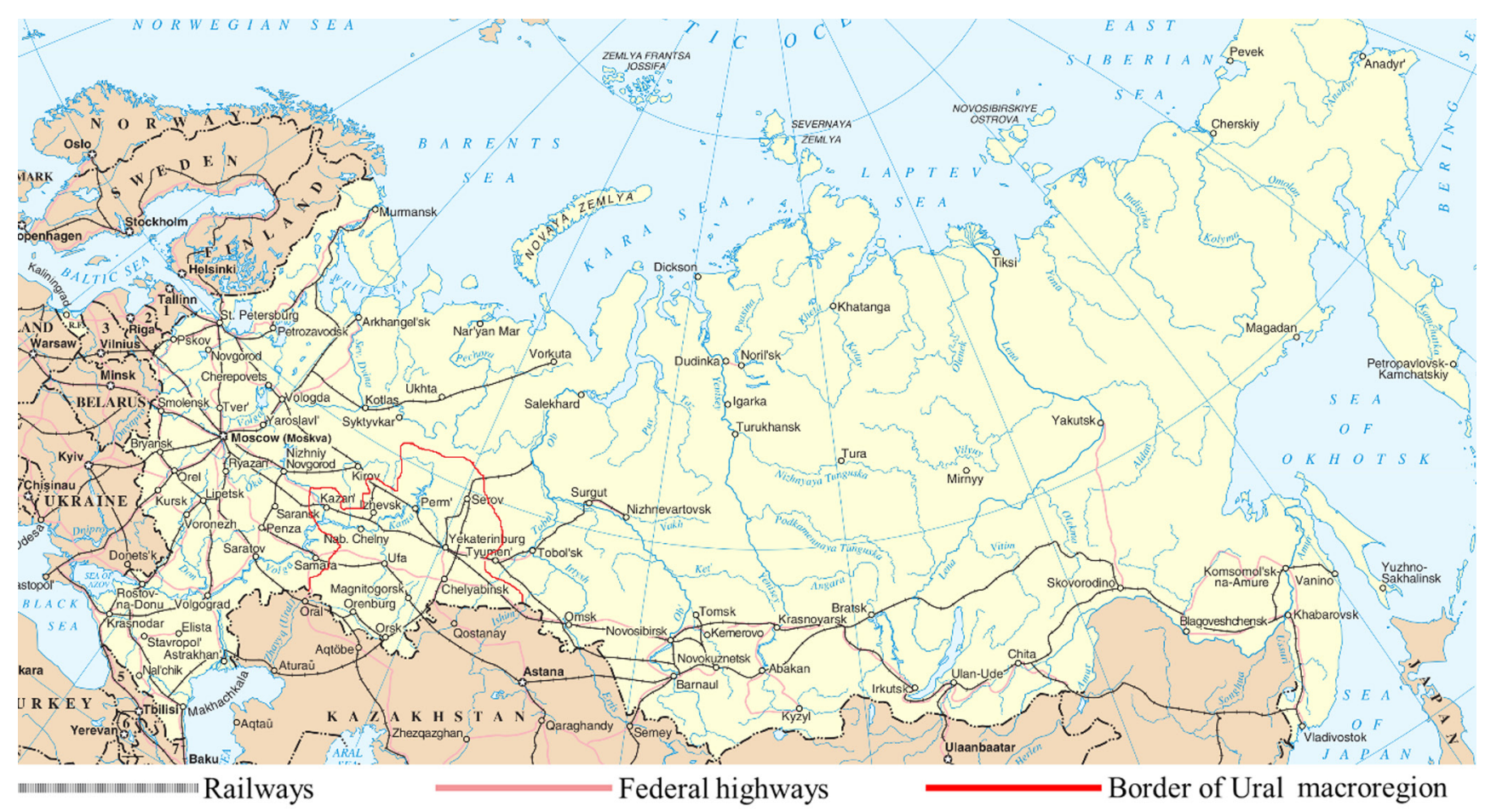

Figure 1. Map of the main roads in Russia 
The increasing opportunities for remote work lead to concentration of the population in metropolitan areas, migration to warmer countries with cheap life (for example, many IT-companies are based in India) or regions. With just 54 per cent of the world's population, cities account for more than 80 per cent of global GDP (United Nations Human Settlements Programme, 2016, p. 31).

The transformation of geographical factors requires new and reinterpreted old approaches to regional development management: these include concepts 'cluster' and 'smart specialization', regional foresight, paradigms of studying the region as a quasi-state, quasi-corporation, market area and region-society (Topoleva, 2019).

\section{Institutional factors}

The fourth industrial revolution changes the system of economic relations. It increases the anonymity and remoteness of contacts and includes artificial intelligence and robotic systems in the chain of interactions.

Trust in this system becomes an extremely important factor. E. Durkheim (1953) said that actors must trust each other more and more often than ever in the conditions of a new mechanical solidarity, otherwise effective interaction and coordinated collective actions become impossible. However, the level of trust in the world community does not tend to grow. The world's population is worried about the future in the digital age and that technological progress will get out of control. In this light, the results of Edelman Trust Barometer (Edelman Trust Barometer 2020: Global Report, p. 15) for 2020 are of particular interest: $61 \%$ of respondents believe that the pace of change in technology is too fast; $66 \%$ worry that technology will make it impossible to know if what people are seeing or hearing is real; and $61 \%$ think that government does not understand emerging technologies enough to regulate them effectively.

Developed countries have adopted programs to ensure their transition to the digital economy and that of public administration to platform solutions since the beginning of the 2010s.

Digital technologies penetrate all areas of people's private and professional lives, even if these technologies appear to be the prerogative of exclusively human interactions. These technologies help to assess and create better laws (Rakhmeeva, 2019) and to interpret them. For example, cybercourt for cybercrime-related cases appeared in
China ${ }^{1}$. A Russian company has developed legal assistants: MegaFon's chatbot 'Legal Ape'2 is a neuronal network that answers questions using legal acts, research papers, and court practice. The robot of 'Pravoved' service Fedor Neurons ${ }^{3}$ answers questions related to consumer protection and family law.

The Japanese concept of 'Society 5.0' (post-industrial society) identifies five main walls of development (Keidanren, 2016): ministries and agencies, legal system, technologies, human resources, social acceptance. Three 'walls' out of five can be called institutional. No geographical barriers to development have been identified.

Researchers identified similar barriers (legal system, technologies, human resources) in Vietnam (Wrana \& Nguyen, 2019).

Digitalization of relationships promotes institutional proximity that recalls 'the set of practices, laws, rules and routines that facilitate collective action' (Lazzeretti \& Capone, 2016, p. 5857). On the other hand, it creates a need for 'Russia, Europe, and the world as a whole to overcome a series of new deep conflicts. One of such conflicts (if not the main one) is the clash of identities' (Gorshkov, 2015, p. 275).

S.D. Bodrunov (2019, p. 6) highlights that the new world order has not been fully established yet. He also points out the growth of regional disparities, the impossibility of full realization of the potential and promising technological progress' as key contradictions for development in the era of the fourth industrial revolution. 'The system of wealth inequality will be replaced by the inequality of skills and talents ... Humanity has become the most powerful geobiological force (in accordance with the concept of noosphere of V. Vernadsky (1988)), and will face the need to move from the consumption of natural resources to the reproduction of geobiocenoses' (Bodrunov, 2019, p. 9).

The role of innovation for competitiveness and long-term economic growth increases in the period of scientific and technological revolutions. However, countries and their regions differ significantly in terms of innovation. In this respect, one cannot but agree with the statement of D. North and R. Thomas that innovation, accumulation of

https://www.japantimes.co.jp/news/2019/12/07/ asia-pacific/crime-legal-asia-pacific/ai-judges-verdictsvia-chat-app-brave-new-world-chinas-digital-courts/\#.XgRhYSMueUn

${ }^{2}$ http://lawyers.megafon.ru/legalape

3 https://fedor.ai/ 
capital is growth itself $(1973$, p. 2), and the factors of development are hidden deeper.

The four-step spiral paradigm includes institutions of civil society, which is the final consumer of innovation and has a significant impact on the creation of knowledge and technology (Carayannis \& Grigoroudis, 2016, p. 31). Russian experts note 'the importance of creating an effective institutional environment for economic development based on innovation', while 'it is more appropriate to form an adequate institutional environment at the regional level, since the national economic system of the Russia is extremely spatially heterogeneous' (Lyashenko, 2018, p. 172).

\section{Methodology and data}

The proposed methodology is based on comparative analysis of regions' development levels as well as their geographical and institutional characteristics. The latter are investigated with the help of rankings.

We are going to use the average values of indicators for a 5-year period (2014-2018) to smooth out random errors.

Traditionally, the level of gross regional product (GRP) per capita has been used as an indicator of regional development.

Geographical factors that can influence regional economic growth are as follows:

- Agricultural land area (Agr);

- Mining of minerals per capita (Min);

- Transport and geographical location estimated as

$$
\begin{gathered}
\text { Trans }=\frac{\text { Rail }_{i}}{\text { Max }_{i=1}^{7}[\text { Rail }]} \cdot 10+ \\
+\frac{\text { Auto }_{i}}{\operatorname{Max}_{i=1}^{7}[\text { Auto }]} \cdot 10+A d v+D i s,
\end{gathered}
$$

where Rail is the density of public railways, $\mathrm{km}$ of tracks per $10,000 \mathrm{~km}^{2}$ of territory; Auto, the density of paved public roads, $\mathrm{km}$ of tracks per $1000 \mathrm{~km}^{2}$ of territory; $A d v$, availability of transport advantages; Dis, geographical disadvantages.

Regulatory environment is a synergy of formal and informal institutions. We intend to make a comprehensive assessment of formal and informal institutions and compare the regions in terms of their institutions. Since there is a lag in the influence of institutions on economic activities, for our analysis we are going to use the 2016 data.

We systematized the key legal norms that have a significant impact on economic activities in Industry 4.0. Table 2 indicates the main norms of the Ural regions, with each element of the institutional environment corresponding to 1 point. The quality of the formal institutional condition for development in Industry 4.0 is the sum of the points:

$$
\begin{gathered}
F I=\sum n_{i} \\
n_{i}=\left\{\begin{array}{c}
1, \text { approved document with an explicit } \\
\text { namereflecting the presence of the element } \\
0 \text {, document or reference to the corresponding } \\
\text { element wasnot detected } \\
0,5, \text { the element is mentioned } \\
\text { inthe general strategy document }
\end{array}\right.
\end{gathered}
$$

From our point of view, the key development institutions in Industry 4.0 for old industrial regions are the regional innovation strategy, regional industrial policy, regional program of digital economy, legal statement technology of the $5^{\text {th }}$ and $6^{\text {th }}$ technological order as a priority, official support of university-business cooperation and specialized infrastructure.

The quality of the informal institutional environment of this or that economic activity was assessed with the help of indirect indicators (the level of trust of entrepreneurs in the authorities, the level of honesty of entrepreneurs and officials):

$$
\begin{gathered}
\text { inFI }=\frac{\text { Trust }_{i}}{\operatorname{Max}_{i=1}^{7}[\text { Trust }]} \cdot 10+ \\
+\frac{\frac{\operatorname{Min}_{i=1}^{7}[\text { Crime }]}{\text { Crime }_{i}} \cdot 10+\frac{\text { Min }_{i=1}^{7}[\text { Guilty }]}{\text { Guilty }_{i}} \cdot 10}{2}+ \\
+\frac{\text { Min }_{i=1}^{7}[\text { Corruption }]}{\text { Corruption }_{i}} \cdot 10
\end{gathered}
$$

where Trust is the share of entrepreneurs who believe that regional authorities contribute to business development, \%; Crime, the average number of incidents of economic crime registered annually per 1,000 enterprises in 2014-2016; Guilty, the average number of people committing economic crimes every year per 1,000 enterprises in 2014-2016; Corruption, is the average number of corruption-related crimes registered annually per 1,000 officials in 2014-2016.

The propensity of entrepreneurs to innovate and the receptivity of society as consumers of innovation are important informal characteristics in Industry 4.0. Sociological research can assess 
these characteristics. Unfortunately, no such research has been done for Russian regions, which explains the absence of relevant data.

All indicators are normalized relative to the maximum in the aggregate on a 10-point scale for comparability of factors. The normalized indicator was defined as:

$$
\text { NIndicator }=\frac{\text { Indicator }_{i}}{\operatorname{Max}_{i=1}^{7}[\text { Indicator }]} \cdot 10 .
$$

As we have specified above, our research focuses on the Ural macro-region (Fig. 1), which includes Sverdlovsk, Chelyabinsk, Kurgan, Orenburg and Perm regions and the republics of Bashkortostan and Udmurtia ${ }^{4}$.

The Ural macro-region occupies the leading position in terms of industrial production and potential in Russia. In the $21^{\text {st }}$ century, the Urals faced problems of deindustrialization, which resulted in the macro-region's shrinking share in a number of indicators of the Russian economy (Si-

${ }^{4}$ Administrative division of the Russian Federation includes such equal in rights types of regions as oblast, krai, republic, autonomous oblast, autonomous okrug, city of federal significance. lin, Animitsa, \& Novikova, 2017, p. 2). The search for the causes of the macro-region's decline and ways of further growth makes it particularly interesting for research.

Having the necessary material and human resources to create, implement and promote innovation, Ural regions are quite different in their levels of development, which may provide us with some interesting insights into the significance of institutional and geographical factors for territorial development.

Table 1 compares the geographical characteristics of Ural regions. The data in Table 1 are taken from official statistical sources ${ }^{5}$.

Table 2 shows the data on formal and informal institutional conditions (regulatory environment) in Ural regions.

\section{Results and discussion}

Table 3 shows normalized estimates of geographical and institutional factors. The numbers of the regions in Table 3 correspond to their numbers in Fig. 2 and 7.

\section{${ }^{5}$ https://www.gks.ru/folder/210/document/13204}

Table 1

Comparison of geographical characteristics of Ural regions

\begin{tabular}{|c|c|c|c|c|c|c|c|}
\hline $\begin{array}{l}\text { Average value of indicator for } \\
2014-2018\end{array}$ & $\begin{array}{c}\text { Sverdlovsk } \\
\text { region }\end{array}$ & $\begin{array}{c}\text { Chelyabinsk } \\
\text { region }\end{array}$ & $\begin{array}{c}\text { Kurgan } \\
\text { region }\end{array}$ & \begin{tabular}{|c|} 
Orenburg \\
region
\end{tabular} & $\begin{array}{c}\text { Perm } \\
\text { region }\end{array}$ & $\begin{array}{l}\text { Bashkorto- } \\
\text { stan }\end{array}$ & Udmurtia \\
\hline GRP per capita, rubles & 457406 & 360323 & 222671 & 411918 & 429283 & 343549 & 354795 \\
\hline Population, ths people & 4325 & 3493 & 853 & 1985 & 2627 & 4064 & 1514 \\
\hline Agricultural land area, thousand ha & 2577 & 5096 & 4458 & 10816 & 2839 & 7329 & 1841 \\
\hline Mining of minerals per capita, rubles & 14145 & 17518 & 3474 & 202003 & 105956 & 55251 & 120253 \\
\hline $\begin{array}{l}\text { Density of public railways, } \mathrm{km} \text { of } \\
\text { tracks per } 10,000 \mathrm{~km}^{2} \text { of territory }\end{array}$ & 181 & 203 & 104 & 117 & 98 & 102 & 185 \\
\hline $\begin{array}{l}\text { Density of paved public roads, km } \\
\text { of tracks per } 1000 \mathrm{~km}^{2} \text { of territory }\end{array}$ & 123 & 204 & 132 & 167 & 133 & 293 & 244 \\
\hline Availability of transport advantages & $\begin{array}{c}+2 \text { (key } \\
\text { transna- } \\
\text { tional and } \\
\text { interre- } \\
\text { gional } \\
\text { transport } \\
\text { corridors, } \\
\text { interna- } \\
\text { tional } \\
\text { airport) }\end{array}$ & $\begin{array}{c}+1 \text { (inter- } \\
\text { national } \\
\text { airport) }\end{array}$ & 0 & \begin{tabular}{|c|}
+2 (key \\
transna- \\
tional and \\
interre- \\
gional \\
transport \\
corridors, \\
interna- \\
tional \\
airport)
\end{tabular} & \begin{tabular}{|c|}
+3 (key \\
transna- \\
tional and \\
interregion- \\
al transport \\
corridors, \\
includ- \\
ing river \\
transport, \\
internation- \\
al airport)
\end{tabular} & $\begin{array}{c}+3 \text { (key } \\
\text { transnational } \\
\text { and interre- } \\
\text { gional trans- } \\
\text { port corri- } \\
\text { dors, access } \\
\text { via rivers } \\
\text { to } 5 \text { seas, } \\
\text { international } \\
\text { airport) }\end{array}$ & $\begin{array}{c}+3 \text { (key } \\
\text { transna- } \\
\text { tional and } \\
\text { interregion- } \\
\text { al transport } \\
\text { corridors, } \\
\text { access via } \\
\text { rivers to } 3 \\
\text { seas, inter- } \\
\text { national } \\
\text { airport) }\end{array}$ \\
\hline Geographical disadvantages & 0 & $\begin{array}{l}-1 \text { (trans- } \\
\text { border } \\
\text { crime) }\end{array}$ & $\begin{array}{c}-1 \\
\text { (trans- } \\
\text { bor- } \\
\text { der- } \\
\text { crime) }\end{array}$ & \begin{tabular}{|c|}
-2 (lat- \\
itudinal \\
length, \\
low pop- \\
ulation \\
density, \\
transbor- \\
der crime)
\end{tabular} & 0 & 0 & 0 \\
\hline
\end{tabular}


Analysis of the regulatory environment (institutional factors) of the old Ural industrial regions

\begin{tabular}{|c|c|c|c|c|c|c|c|}
\hline Element of regulatory environmen & $\begin{array}{l}\text { Sverd- } \\
\text { lovsk } \\
\text { region }\end{array}$ & $\begin{array}{l}\text { Chelya- } \\
\text { binsk } \\
\text { region }\end{array}$ & $\begin{array}{c}\text { Kurgan } \\
\text { region }\end{array}$ & $\begin{array}{l}\text { Oren- } \\
\text { burg } \\
\text { region }\end{array}$ & \begin{tabular}{c|c|} 
Perm \\
region
\end{tabular} & $\begin{array}{l}\text { Bashkor- } \\
\text { tostan }\end{array}$ & $\underset{\text { tia }}{\text { Udmur- }}$ \\
\hline \multicolumn{8}{|c|}{ Formal institutional factors } \\
\hline $\begin{array}{l}\text { Technological (industrial, innovative) development } \\
\text { as priority of socio-economic development strategy }\end{array}$ & + & + & - & - & + & + & - \\
\hline $\begin{array}{l}\text { Conception/ strategy of technological (industrial, } \\
\text { innovative) regional development }\end{array}$ & + & + & - & - & - & + & + \\
\hline $\begin{array}{l}\text { List of the top priority technologies, related to the } \\
\text { region's characteristics and technologies of the } 5^{\text {th }} \\
\text { and } 6^{\text {th }} \text { technological order }\end{array}$ & \pm & - & - & $\pm^{1}$ & - & + & $\pm^{1}$ \\
\hline Regional law on industrial policy & + & + & + & + & + & + & + \\
\hline $\begin{array}{l}\text { Regional law on science, technological development } \\
\text { and innovation }\end{array}$ & + & - & + & - & + & + & $+^{*}$ \\
\hline Regional law on small business support & + & + & + & + & + & + & + \\
\hline $\begin{array}{l}\text { Regional legal norms on financial support of science, } \\
\text { technological and industrial development and inno- } \\
\text { vation }\end{array}$ & + & + & \pm & + & +- & + & \pm \\
\hline $\begin{array}{l}\text { Regional program on development of science, techno- } \\
\text { logical and industrial development and innovation }\end{array}$ & + & + & + & $\pm^{1}$ & + & + & + \\
\hline $\begin{array}{l}\text { Regional legal norms on digital economy develop- } \\
\text { ment }\end{array}$ & $+^{*}$ & $+^{*}$ & $+^{*}$ & $+^{*}$ & $+^{*}$ & $+^{*}$ & - \\
\hline Regional import substitution plans & + & + & $+^{*}$ & + & + & + & + \\
\hline $\begin{array}{l}\text { Description of approaches to supporting coopera- } \\
\text { tion between industrial enterprises, large and small } \\
\text { businesses, and universities in the legislation }\end{array}$ & + & + & - & - & - & \pm & $\pm^{3}$ \\
\hline $\begin{array}{l}\text { Description of spatial forms of cooperation and } \\
\text { development in the region in the legislation }\end{array}$ & + & \pm & \pm & + & + & + & + \\
\hline $\begin{array}{l}\text { Legally required children's technological creativity } \\
\text { support }\end{array}$ & + & $+^{*}$ & $+^{*}$ & $+^{*}$ & - & + & $+^{*}$ \\
\hline $\begin{array}{l}\text { Legally required regular competitions of professional } \\
\text { skills in the industrial sphere }\end{array}$ & + & + & - & - & + & + & + \\
\hline $\begin{array}{l}\text { FI (Quality of formal institutional conditions), points } \\
\text { as of } 2016\end{array}$ & 14 & 10.5 & 6 & 7 & 9.5 & 12.5 & 8.5 \\
\hline \multicolumn{8}{|c|}{ Informal institutional factors } \\
\hline $\begin{array}{l}\text { The share of entrepreneurs who believe that regional } \\
\text { authorities promote/ hinder business development, \% }\end{array}$ & $23 / 41$ & $20 / 62$ & $12 / 42$ & $26 / 33$ & $16 / 39$ & $44 / 28$ & $12 / 52$ \\
\hline \multicolumn{8}{|l|}{ Level of integrity in the economic environment: } \\
\hline $\begin{array}{l}\text { The average number of economic crimes registered } \\
\text { annually per } 1,000 \text { enterprises in } 2014-2016\end{array}$ & 17 & 15 & 39 & 21 & 21 & 25 & 26 \\
\hline $\begin{array}{l}\text { The average number of people committing economic } \\
\text { crimes per } 1,000 \text { enterprises in } 2014-2018\end{array}$ & 7 & 10 & 14 & 13 & 10 & 9 & 15 \\
\hline $\begin{array}{l}\text { Level of corruption: the average number of corrup- } \\
\text { tion-related crimes registered annually per } 1,000 \\
\text { officials in } 2014-2018\end{array}$ & 6 & 7 & 5 & 4 & 8 & 6 & 5 \\
\hline $\begin{array}{l}\text { inFI (Quality of informal institutional conditions), } \\
\text { points as of } 2016\end{array}$ & 21.2 & 16.7 & 17.4 & 18.9 & 15.0 & 22.0 & 15.5 \\
\hline
\end{tabular}

Note: + approved document with an explicit name reflecting the presence of the element

- document or reference to the corresponding element was not detected

\pm the element is mentioned in the general strategy document

* a law was passed after 2016

${ }^{1}$ The list duplicates the Federal List without regional specifics.

${ }^{2}$ It is a sub-program of the General Program 'Economic Development'.

${ }^{3}$ The region's strategy sets the task to search for forms of such cooperation.

Source: the author's compilation is based on the survey 'Business Pulse' Foundation of public opinion, 2013. The survey involved 500-800 respondents in each of the regions. https://fom.ru/pulse/region.html? region=56 and official statistical data (cases of abuse of office and bribery were taken into account) http://crimestat.ru/regions_chart total 
Table 3

Comparison of institutional and geographical factors of Ural regions' development

\begin{tabular}{|l|l|c|c|c|c|c|}
\hline № & \multicolumn{1}{|c|}{ Region } & NAgr & NMin & NTransp & NFI & NinFI \\
\hline 1 & Udmurtia & 1.7 & 5.9 & 10 & 6 & 7 \\
\hline 2 & Perm region & 2.6 & 5.2 & 6 & 7 & 7 \\
\hline 3 & Sverdlovsk region & 2.4 & 0.7 & 8 & 10 & 9 \\
\hline 4 & Orenburg region & 10.0 & 10.0 & 6 & 5 & 9 \\
\hline 5 & Bashkortostan & 6.8 & 2.7 & 9 & 9 & 10 \\
\hline 6 & Chelyabinsk region & 4.7 & 0.9 & 8 & 8 & 8 \\
\hline 7 & Kurgan region & 4.1 & 0.1 & 4 & 4 & 7 \\
\hline
\end{tabular}

Source: the author's own calculations

Figure 2 shows the normalized values of GRP per capita for Ural regions. Sverdlovsk region has the highest level of development and Kurgan region, the lowest.


Figure 2. GRP per capita in Ural regions (normalized average values for 2014-2018), points Source: the author's interpretation

The geographical characteristics of Ural regions are quite diverse. Unlike their neighbours, Orenburg region and Bashkortostan have a huge agricultural land area and favorable climate for agriculture (Fig. 3). Orenburg region is the leader in the sphere of mineral mining. Both regions are among the main oil producing Russian regions. Sverdlovsk and Chelyabinsk regions, on the contrary, have low levels of mineral production (Fig. 4) and high levels of general development.

The key transnational and interregional transport corridors go through Chelyabinsk and Kurgan regions. River transport corridors go through Perm region, Bashkortostan and Udmurtia. The density of the road network varies by up to two times in the regions. The aggregate position of the regions in terms of the quality of their transport infrastructure (NTransp) is shown in Fig. 5.

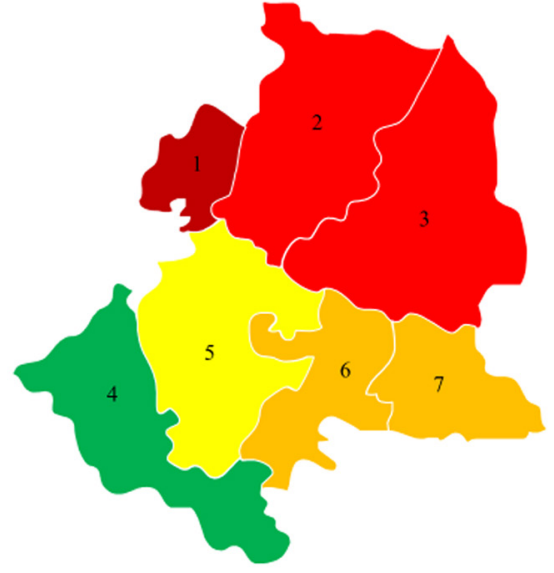

Ranking of gricultural land area, points



Figure 3. Agricultural land area in Ural regions (normalized average values for 2014-2018), points Source: author's interpretation

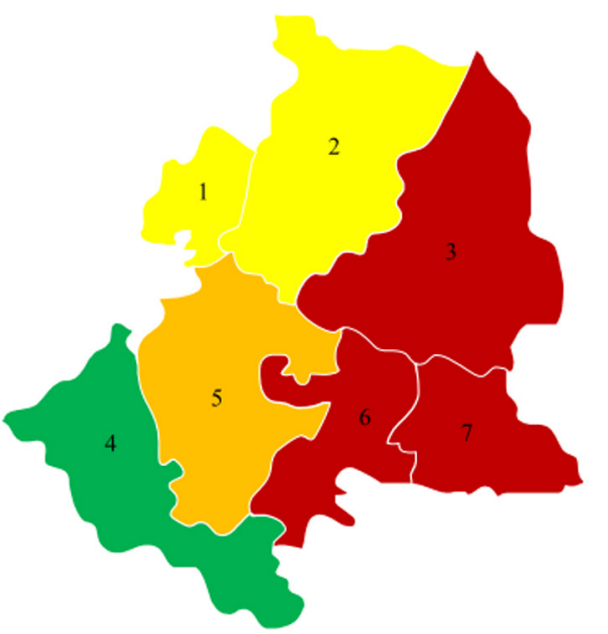

Ranking of mining per capita, points



Figure 4. Mining of minerals per capita in Ural regions (normalized average values for 2014-2018), points Source: author's interpretation

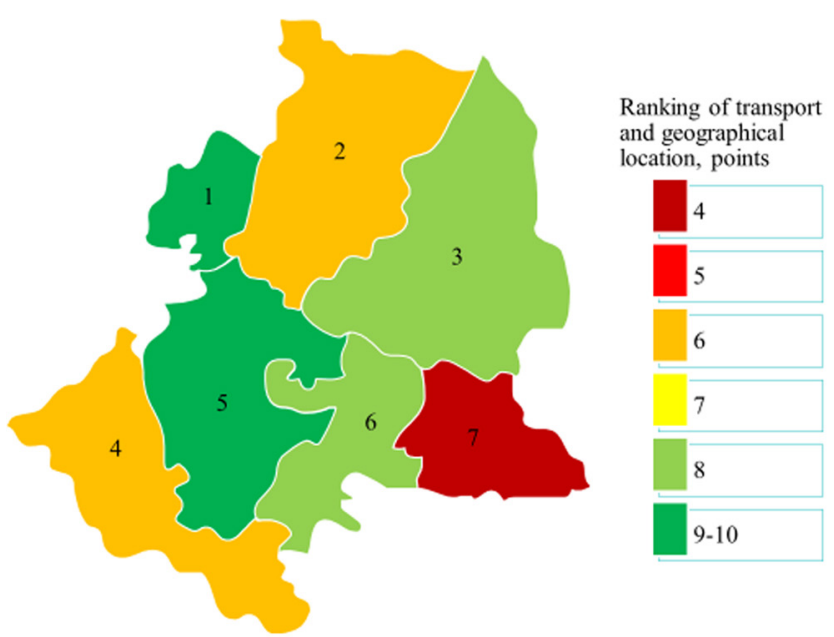

Figure 5. Transport infrastructure and geographical location of Ural regions (normalized average values for 2014-2018), points Source: author's interpretation 
The quality of formal institutions varies significantly across Ural regions (Fig. 6). Regional documents (e.g. strategies and programs) - the documents that form the legal foundation of industrial and innovative activities - generally contain little information about technological development.
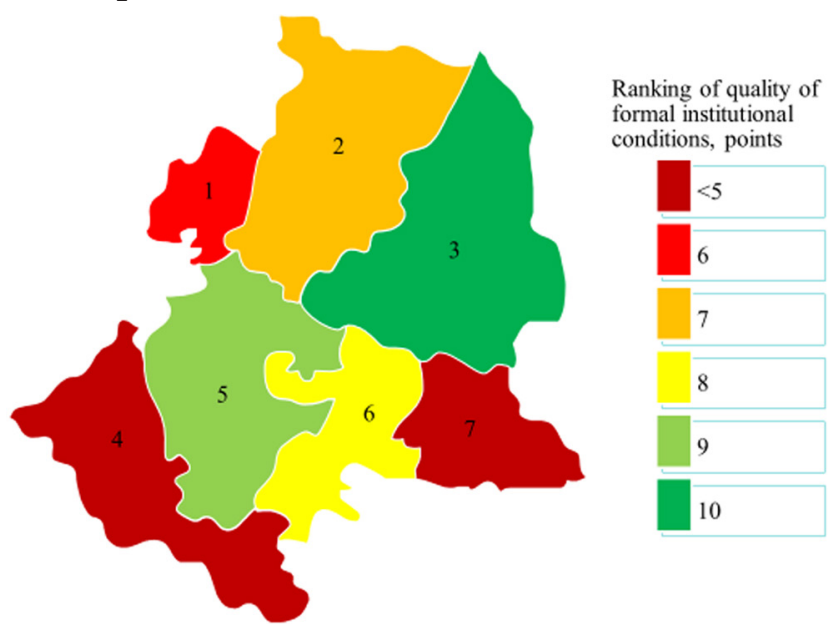

Figure 6. Quality of formal institutions in Ural regions (normalized values as of 2016), points Source: author's interpretation

Development strategies of most Ural regions contain general information about innovation support without providing further details regar-ding specific industries or technologies. Although official information on investment policies is made available online, we have managed to find no such resources concerning governmental support and priorities for innovative development. This may signify a lack of focus on technological and industrial development in Ural regions.

Bashkortostan with its concept of Bashkir technological initiative stands out among other regions. Its goal is to create fundamental scientific and technological bases for ensuring longterm competitive advantages and sustainable development.

In the strategic documents of Kurgan region, there is a focus on the development of basic industries, which signifies a low level of innovative development. The innovative development strategies in Orenburg region and Udmurtia also leave much to be desired, despite the adoption of relevant documents in the innovation field. On the contrary, strategies of Russian regions with developed innovation infrastructure include such priorities as innovative economy, modernization of basic industries, the use of energy saving products and technologies as well as envi- ronmentally friendly products and technologies in all spheres of public life.

We have not found significant differences in the quality of informal institutions across Ural regions (Fig. 7).

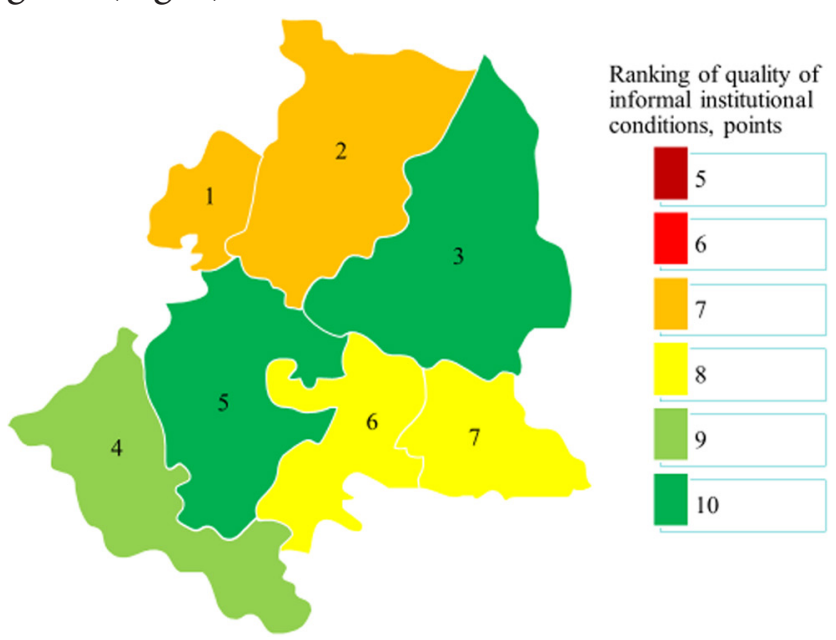

Figure 7. Quality of informal institutions in Ural regions (normalized average values for 2014-2016), points Source: the author's interpretation

Kurgan region has the weakest position both from the institutional and geographical point of view, which is reflected in its being the least developed region in the Urals. More attention should be paid to managing the regulatory environment to enhance the region's economic performance.

Despite the low quality of regulation, Orenburg region has better potential for development due to its mineral resources. Its institutional environment can be described as extractive and we can expect a decline in industrial, technological and socio-economic development in the long term.

Bashkortostan is characterized by a medium level of development despite the favorable institutional conditions and transport and geographical factors. This situation correlates with its high resource dependence (Bashkortostan is one of the largest oil regions in Russia).

Perm, Sverdlovsk and Chelyabinsk regions have weaker competitive positions in terms of geography in comparison with their neighbors and at the same time manage to demonstrate a high level of economic development. The latter can be explained by the quality of institutional conditions in these regions. The regulatory environment of these regions is inclusive. We predict the sustainable development of these regions in the context of the fourth industrial revolution 
and greater stability during global and internal crises. However, this question requires further attention.

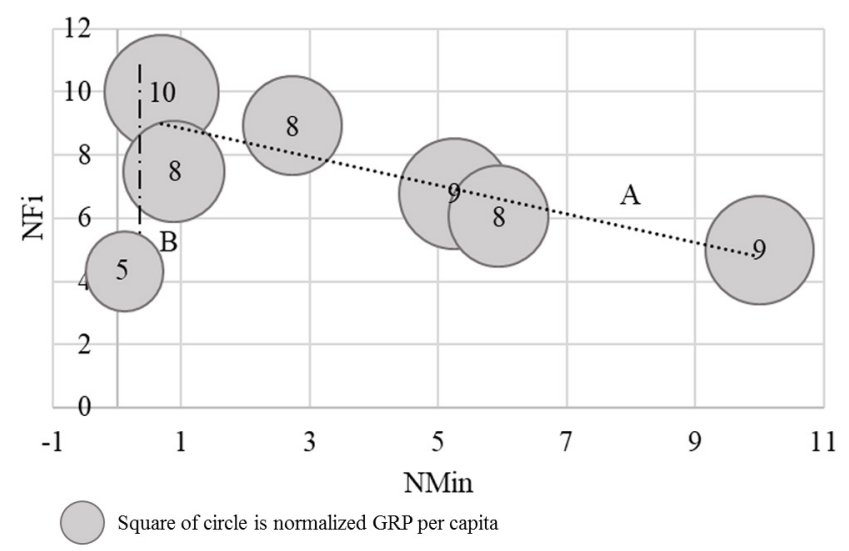

Figure 8. Dependence of GRP per capita on institutional (NFi) and geographical (mining, NMin) factors in Ural regions Source: the author's interpretation

Since the purpose of the research was to identify the comparative role of geographical and institutional factors (Fig. 8) in economic development of regions, it seems necessary to point out that our analysis does not exclude the influence of other factors in additions to the ones discussed in this article.

\section{Conclusions}

A number of old industrial regions in Russia remain highly dependent on geographical factors. In other territories, however, geographical factors completely lose their former significance and institutional factors become more important. See, for example, Fig. 8 above: the regions with above-average GRP per capita are located along the negative slope line (Line A), while the regions with low mining levels are located along the vertical line (Line B) and show an increase in GRP per capita with an increase in the quality of the regulatory environment.

It is interesting to compare the Ural regions with the study conducted by Moralles et al. of 26 Brazilian states: 'these paradoxes in some cases reflect spatial competition and in others negative spillovers or self-reinforcing trends in innovation and social investment' (Moralles et al., 2019, p. 382). It can be assumed that the complexity of the impact of geographical and institutional factors will persist in countries with a large territory, extended in space and resource-dependent. This question, however, requires further investigation in regional studies.

Russian regionalist N.V. Zubarevich has researched a similar problem of the influence of geographical and institutional factors by looking at the development of Russian regions in the 2000s (2010, p. 13): 'numerous examples show that the role of institutions as incentives for development is still secondary, while the advantages of the "first nature" and the agglomeration effect remain more significant'.

Our research shows a shift towards the greater significance of institutional factors in some Russian regions in the 2010s. There is a significant correlation between the level of regional development and formal institutions (the quality of regulation). Differences in the informal institutional environment of Ural regions are small, which can be explained by the significant spatial proximity of these regions and their long relationship history as well as the long period of transformations of informal institutions. The data indicates the increasing importance of the institutional factors in comparison with the geographical ones in Industry 4.0.

In the 2020s, Russia is preparing to launch a regulatory 'sandbox', that is, to introduce special legal regimes for systems based on big data, blockchain, neurotechnology and AI, quantum technologies, robotics, wireless communications, virtual and augmented reality in certain territories. This will reduce legal uncertainty, stimulate the introduction of new solutions to the market, weed out non-working models faster, and reduce costs. This phenomenon will be a clear reflection of the impact of institutional factors on economic development. The regions that have ventured to create a regulatory 'sandbox' on their territory will be able to significantly outpace other regions and reach a new growth trajectory faster.

Thus, it can be concluded that Russian regional authorities should put more effort into creating a better regulatory environment for innovation and industry in order to meet modern development challenges more efficiently.

\section{References}

Acemoglu, D., \& Robinson, J. (2012). Why Nations Fail: The Origins of Power, Prosperity, and Poverty. NY: Crown Publishers. 
Animitsa, E.G., \& Rakhmeeva, I.I. (2020). Third institutional revolution and change of structure of economic relations. Scientific Works of the Free Economic society of Russia, 222(2), 206-218. doi: 10.38197/2072-2060-2020-222-2-206-218

Bodrunov, S.D. (2019). Noonomica: conceptual framework of a new paradigm of development. Journal of New Economy, 20(1), 5-12. (In Russ.). doi: 10.29141/2073-1019-2019-20-1-1

Cappellano, F., \& Rizzo, A. (2019). Economic drivers in cross-border regional innovation systems. Regional Studies, Regional Science, 6(1),460-468. doi: 10.1080/21681376.2019.1663256

Carayannis, E., \& Grigoroudis, E. (2016) Quadruple Innovation Helix and Smart Specialization: Knowledge Production and National Competitiveness.Foresight and STI Governance, 10(1), 31-42. doi: 10.17323/1995-459x.2016.1.31.42

Chen, Z., Haynes, K. E., Zhou, Y., \& Dai, Z. (2019). High speed rail and China's new economic geography: Impact assessment from the regional science perspective. Cheltenham: Edward Elgar.

Connor, R., \& Dovers, S. (2004). Institutional Change for Sustainable Development. Cheltenham: Edward Elgar.

Durkheim, E., \& Pocock, D.F. (1953). Sociology and Philosophy. Glencoe: Free Press.

Edelman Trust Barometer 2020: Global Report. (2020). Edelman. Retrieved from: https://cdn2. hubspot.net/hubfs/440941/Trust\%20Barometer\%202020/2020\%20Edelman\%20Trust\%20Barometer\%20Global\%20Report.pdf

Frolov, D.P. (2015). Do Institutions Matter in Spatial Economics? Spatial economics, 1, 14-37. (In Russ.). doi: 10.14530/se.2015.1.014-037

Glazyev, S.Yu., Ajvazov, A.E., \& Belikov, V.A. (2018). The future of the world economy is an integrated world economic structure. Economy of Region, 14(1), 1-12. doi: 10.17059/2018-1-1

Gorshkov, M.K. (2015). Russian identity in the context of new challenges and risks. Scientific Works of the Free Economic Society of Russia, 195(6), 274-290. (In Russ.)

Keidanren, (Japan Business Federation). (2016). Toward realization of the new economy and society - Reform of the economy and society by the deepening of 'Society 5.0'. Retrieved from: https:// www.keidanren.or.jp/en/policy/2016/029 outline.pdf

Kirdina, S.G. (2016). The role of institutions and geography in economic development: actual discussion in heterodox economy. Spatial Economics, 3, 133-150. (In Russ.). doi: 10.14530/ $\underline{\text { se.2016.3.133-150 }}$

Lazzeretti, L., \& Capone, F. (2016). How proximity matters in innovation networks dynamics along the cluster evolution. A study of the high technology applied to cultural goods. Journal of Business Research, 69, 5855-5865.

Lorenz, A., Hemmer, H.-R., \& Ahlfeld S. (2005). The Economic Growth Debate - Geography Versus Institutions: Is There Anything Really New? Entwicklungsökonomische Diskussionsbeiträge, 34, 19.

Lyashenko, E.A. (2018). Experience and problems of formation of the regional institutional environment of functioning of Technopark structures. Azimut of Scientific Research: Economics and Administration, 7(3), 172-175. (In Russ.) lishers.

Marx, K. (1894). Capital: A Critique of Political Economy. Volume III. NY: International Pub-

Mironov, B.N. (2014). Who is guilty: nature or institutions? Geographical factor in the history of Russia. Social sciences and modernity, 5, 130-141. (In Russ.)

Mokronosov, A.G., \& Anisimov, A.V. (2019). Improving the institutional environment strategic design intangible assets of the territory. Scientific Works of the Free Economic Society of Russia, 215(1), 239-263. (In Russ.)

Moralles, H.F., Silveira, N.J.C., \& Rebelatto, D.A.N. (2019) Spatial spillovers of innovation and transport in Brazil. Area Development and Policy, 4(4), 382-398. doi: 10.1080/23792949.2018.1549502

Morisson, A. (2019) Knowledge Gatekeepers and Path Development on the Knowledge Periphery: The Case of Ruta N in Medellin, Colombia. Area Development and Policy, 4(1), 98-115. doi: $10.1080 / 23792949.2018 .1538702$

North, D. (1990). Institutions, Institutional Change and Economic Performance. Cambridge: Cambridge University Press. 
North, D., \& Thomas, R. (1973). The Rise of Western World: A New Economic History. Cambridge: Cambridge University Press.

Parent, O., \& Zouache, A. (2012). Geography Versus Institutions: New Perspectives on the Growth of Africa and the Middle East. Journal of Institutional and Theoretical Economics, 168(3), 488-518.

Pipes, R.E. (1974). Russia Under the Old Regime. NY: Charles Scribner's Sons.

Rakhmeeva, I.I. (2019). The digitalization in the service the asessment of regulatory legal acts. Advances in Economics, Business and Management Research Proceedings of the $1^{\text {st }}$ International Scientific Conference, 178-181. doi: 10.2991/MTDE-19.2019.34

Rodrik, D., Subramanian, A., \& Trebbi, F. (2002). Institutions Rule: The Primacy of Institutions Over Geography and Integration in Economic Development. NBER Working Paper, 9305, 1-44.

Sachs, J.D. (2003). Institutions Don't Rule: Direct Effects of Geography on Per Capita Income. NBER Working Paper, 9490, 1-12. doi: 10.3386/w9490

Silin, Ya.P., Animitsa, E.G., \& Novikova, N.V. (2017). Trends in the development of the economic space of the Ural macroregion. The Manager, 2(66), 2-11. (In Russ.).

Tambovtsev, V.L. (2019). Sustainable Regional Development: Actual Directions of Institutional Analysis. Journal of institutional Studies, 3, 104-118. (In Russ.). doi: 10.17835/20766297.2019.11.3.104-118

Topoleva, T.N. (2019). Regional development: new theories. Juvenis Scientia, 6, 14-17. (In Russ.). doi: $10.32415 /$ jscientia.2019.06.03

United Nations Human Settlements Programme. (2016). Urbanization and Development: Emerging Futures. World Cities Report. United Nations Human Settlements Programme.

Vernadsky, V.I. (1988). Scientific thought as a planetary phenomenon. Moscow: Nauka. (In Russ.).

Vogelpohl, T., \& Aggestam, F. (2012). Public policies as institutions for sustainability: potentials of the concept and findings from assessing sustainability in the European forest based sector. European Journal of Forest Research, 131(1), 57-71.

Wrana, J., \& Nguyen, T.X.T. (2019) 'Strategic coupling' and regional development in a transition economy: what can we learn from Vietnam? Area Development and Policy, 4(4), 454-465. doi: $\underline{10.1080 / 23792949.2019 .1608838}$

Zubarevich, N.V. (2010). Regional development and institutions: Russian specifics. Regional research, 2(28), 3-14.

\section{Information about the author}

Irina I. Rakhmeeva - PhD in Economics, Associate Professor, Department of Regional and $\mathrm{Mu}$ nicipal Economics and Management, Ural State University of Economics (62 $8^{\text {th }}$ Marta Str., 620144, Ekaterinburg, Russian Federation); e-mail: smartreg66@gmail.com

ARTICLE INFO: received September 27, 2020; accepted December 4, 2020

\section{Информация об авторе}

Рахмеева Ирина Игоревна - кандидат экономических наук, доцент кафедры региональной, муниципальной экономики и управления, Уральский государственный экономический университет (Россия, 620144, г. Екатеринбург, ул. 8 Марта, 62); e-mail: smartreg66@gmail.com

ИНФОРМАЦИЯ О СТАТЬЕ: дата поступления 27 сентября 2020 г.; дата принятия к печати 4 декабря 2020 г. 